\title{
ECOLOGICAL PERSPECTIVES ON MANDE POPULATION MOVEMENTS, COMMERCIAL NETWORKS, AND SETTLEMENT PATTERNS FROM THE ATLANTIC WET PHASE (ca. 5500-2500 B.C.) TO THE PRESENT *
}

\author{
George E. Brooks \\ Indiana University
}

I

In this paper I discuss known and probable migrations and areas of settlement of proto-Mande and Mande-speaking groups during eight climate periods spanning the past eight millennia. Recent scholarship concerning west African climate patterns in past times has made feasible provisional periodizations of west African history that are independent of European-derived chronologies. Concomitantly, these historical periodizations offer provocative insights regarding such long-term processes as human migrations and settlement patterns; the diffusion of cultigens and domestic animals; the development of long- distance trade routes; and the use of horse cavalry in warfare.

The provisional historical schema comprising eight climate periods and Map 1 depicting ecological zones are principally derived from the pioneering studies of Sharon E. Nicholson and of Susan and Roderick McIntosh, and from the analyses I have presented elsewhere: (1) The Atlantic Wet Phase which extended from ca. 5500 to ca. 2500 B.C., was succeeded by (2) a two-and-a-half millennia-long period of desiccation. (3) There was a six centuries-long transiton period between ca. 300 B.C. and ca. 300 A.D., during the latter part of which ecological conditions improved sufficiently to permit the development of intraand trans-Saharan commerce. (4) Four centuries of moderate rainfall ca. 300-ca. 700 , and (5) four centuries of abundant rainfall ca. 700-ca. 1100, were followed by (6) a four centuries' long dry period extending from ca. 1100 to ca. 1500 . (7) A brief wet period, ca. 1500 -ca. 1630 , preceded (8) a two centuries-long dry period lasting until ca. $1860 .^{1}$

Like other west African groups, Mande speakers responded to changing climate conditions in a variety of ways, including adapting to changing rainfall 
patterns in a given area, migrating to different locations, taking advantage of circumstances regarding commercial exchanges, or raiding neighboring groups. The principal focus of the paper is the Northern sub-group of Mande speakers, with less discussion regarding the Southwestern and Southeastern sub-groups. The following listing of Mande languages is derived and simplified from classifications published by Joseph Greenberg and Charles S. Bird. ${ }^{2}$

\section{Northern Sub-Group}

Soninke (sahel zone and oases in Mauretania and Mali)

Mandekan: Mandinka; Maninka, including Kuranko; Bamana, including Dyula of Ivory Coast (savanna and savannawoodland zones from the Atlantic to the Volta River)

Susu/Jallonke/Yalunka (coastal region of Guinea-Conakry and northern Sierra Leone)

Vai/Kono (eastern Sierra Leone and southwest Liberia)

\section{Southeastern sub-group}

Busa (northwestern Nigeria)

Bisa; Samo; Sya (Burkina Faso)

Mwa; Nwa; Kweni/Guro; Dan/Gio (central Ivory Coast)

Mano (north-central Liberia)

\section{Southwestern sub-group}

Kpelle/Guerze; Loma/Toma; Gbandi; Gbundi (Liberia)

Mendi; Loko (Sierra Leone)

Map 2, derived from Greenberg's maps A and B, depicts the wide dispersion of Mande speakers across west Africa, from the margins of the Sahara to Liberia, and from Senegambia to Nigeria. Dialects belonging to the Northern subgroup include Soninke, whose speakers reside in the sahel and oases of the southern Sahara; Susu/Jallonke/Yalunka, a dialect closely related to Soninke, but whose speakers today live in the coastal region of Guinea-Conakry and in northern Sierra Leone, hundreds of kilometers to the south of Soninke speakers and separated by a belt of Mandekan speakers; Vai/Kono, two closely-related dialects whose speakers live in clusters 100 kilometers apart in Sierra Leone and Liberia; and Mandekan, whose speakers live dispersed across the savanna heartland of western Africa.

The Southwestern sub-group of Mande languages include Kpelle/Guerze, Loma/Toma, Gbandi, Gbundi, Mendi, and Loko. Speakers of the Southeastern sub-group are widely scattered--Busa in northwestern Nigeria; Bisa, Samo, and Sya in Burkina Faso; Mwa, Nwa, Kweni/Guro, and Dan/Gio in central Ivory Coast; and Mano in northern Liberia. These are manifestly remnants of groups inhabiting larger territories in times past.

Map 1, depicting ecological zones in the 1930-1960 intermediate period, delineates some of the salient geographical characteristics of the present-day location of Mande-speaking groups. Speakers of Northern Mande dialects live in

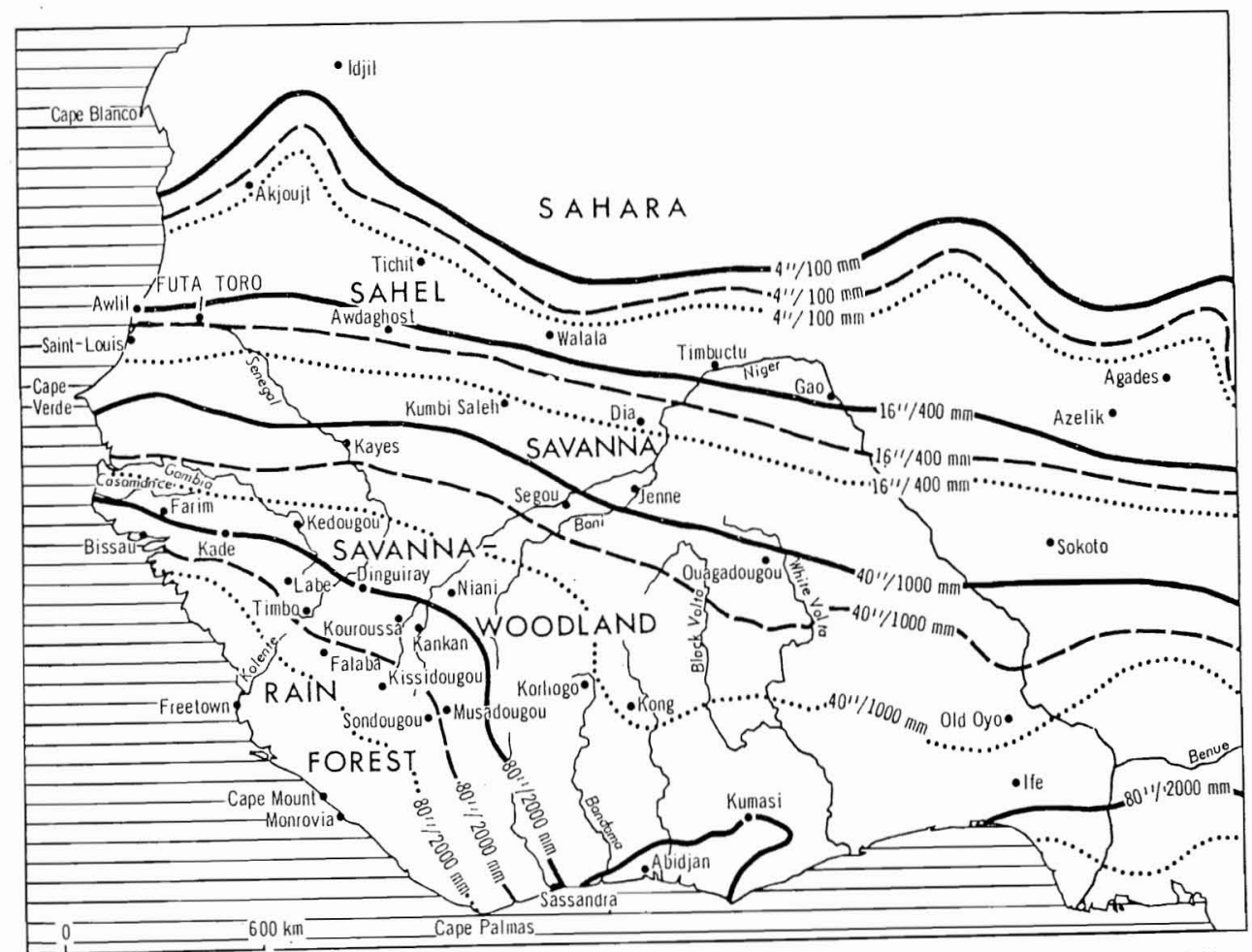

wet periods (ca. 700-1100 A.D.; ca. 1500-1630 A.D.) MAp. Rainfall patterns and limits
of ecological zones in Western Africa.

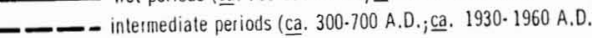

......... dry periods (뜨. 300 B.C. -300 A.D. ; ㄸa. $1100-1500$ A.D. ; ca. 1630.1860 A.D. 
all five ecological zones, Southeastern groups are widely dispersed across three zones, while Southwestern groups are restricted to the forest zone and contiguous areas of savanna-woodland.

How may one account for the present distribution of speakers of Mande languages? Available data regarding population movements, economic activities, state-building, and other historical processes are examined in the context of climate periods and ecological changes. The provisional findings are summarized following.

\section{II}

\section{(1) The Atlantic Wet Phase ca. 5500-ca. 2500 B.C.}

Insofar as linguistic analyses and archaeological research inform historical reconstructions, it may be inferred that proto-Mande speakers lived in dispersed groups in the area between the bends of the Senegal and Niger rivers prior to and during the Atlantic Wet Phase (ca. 5500-2500 B.C.). During these three millennia proto-Mande-speaking hunter-gatherers moved northwards to take advantage of living conditions in the "green" Sahara, which may have had three to four times more rainfall (Figure 1) than during the intermediate period 1930-1960 depicted on Map 1, when rainfall was approximately 100 millimeters annually. During this long wet period the Sahara area had a grasslands environment, with numerous streams, shallow lakes, and swamplands supporting a rich flora and fauna which attracted human settlement. Ecological zones extended much farther north than has subsequently been the case, with forests beginning around $13^{\circ}$ north latitude, i.e., along the Casamance River. $^{3}$

Population groups inhabiting the "green" Sahara included proto-NiloSaharan speakers exploiting the aquatic environment, proto-Mande speaking hunter- gatherers, and proto-Berber speakers from north Africa who introduced goats, sheep, and ndama (west African shorthorn) cattle into Saharan pasturelands. Scenes of humans and animals living during the Atlantic Wet Phase are vividly portrayed in rock paintings and etchings in parts of the Sahara too arid for human habitation today. Hunters are depicted stalking antelopes and ther game, and pastoralists are shown herding sheep, goats, and multi-colored attle. ${ }^{4}$ Members of different groups could learn and adapt lifestyles from one inother; for example, some proto-Mande hunter-gatherers may have acquired ivestock during this period.

\section{(2) ca. 2500 B.C-ca. 300 B.C.}

The climate of west Africa during the two-and-a-half millennia from ca. 2500 B.C. to ca. B.C./A.D. was characterized by progressive desiccation (Figure 1). As ecological conditions worsened, people living in the area of the Sahara sither modified their lifestyles or sought more favorable environments by mizrating north, south, or east into the Nile valley. Herding groups migrating
NORTHERN SUB-GROUP 1 Soninke 1630

2 Susu (637) /3 Dyalonke (192
4 Kono (376) /5 Vai (696)

6 Khasonke (366)

Bamana (67) /9 Dyula/Bamana (196) 12 Liqbi (423)

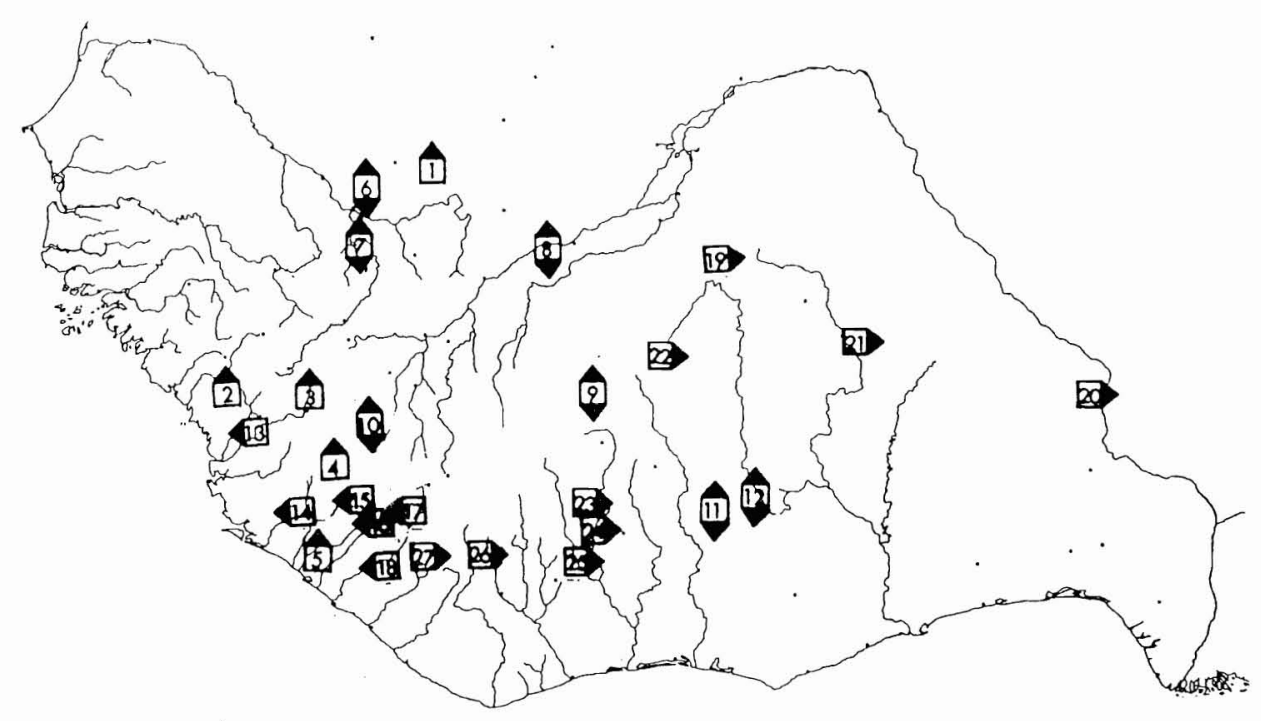

SOUTHWESTERN SUB-GROUP

13 Loko (431)

14 Mendi (4.88)

15 Gbundi (241)

16 Gbandi (236)

17 Loma/Toma (432)

$18 \mathrm{Kpelle/Guerze} \mathrm{(385)}$

SOUTHEASTERN SUB-GROUP >

19 Samo (597) 25 Krent/Guro (407)

20 Busa (132) 26 Dan/Gio (163)

21 Bisa (113)

27 Mano (463)

22 Sya (638)

24 Nwa (562) 
south introduced ndama cattle, goats, and sheep to sub-Saharan pastures, some groups reaching the area of the Niger bend by ca. 2000 B.C.

Groups living in the southern Sahara along the receding shorelines of shallow lakes intensified their collection of wild grains, some of which they began to cultivate. These groups included proto-Mande speakers in the Tichit area of present-day Mauretania who cultivated millet sometime after 2000 B.C., and other groups to the east (proto-Nilo-Saharan speakers?) who domesticated sorghum. These grains came to be grown across the wide expanse of sahel and savanna zones extending from Mauretania and Senegal to the Nile valley. ${ }^{5}$ The pattern of diffusion of Mande sub-groups suggests that the ancestors of Southwestern and Southeastern speakers early adopted cultivation of millet and sorghum and migrated south in search of areas with higher rainfall, while the ancestors of Northern speakers remained in the sahel and margins of the Sahara as hunter-gatherers and herders.

In all probability there were significant population increases among Mande-speaking groups from this period onwards, particularly for cultivators keeping domestic animals whose diets were additionally supplemented by hunting and gathering. The domestication of rice by the 3 rd century B.C. provided an additional grain staple to sustain growing populations. ${ }^{6}$ Given these advantages, it seems likely that Mande-speaking groups increased their numbers more rapidly than potential rivals for some of the most productive soils and pasturelands in west Africa. How far south proto-Mande cultivators ventured during the long period of desiccation is unknown, but it would seem likely that most stayed in the southward-moving savanna zone. Significant migrations farther south into the savanna-woodland zone seem improbable, for that would have required adaptation to unfamiliar environmental conditions with respect to cultivating grains and raising livestock. Indeed, with the progressive increase of rainfall after B.C./A.D., some groups may have moved north to areas their ancestors formerly occupied (Map 1 and Figure 1).

The introduction of horse chariotry among Berber groups living near the Phoenician settlements founded in north Africa after ca. 1000 B.C. had profound consequences for groups living in the Sahara and sahel. Rock paintings and etchings and archeological investigations show that from approximately the 7 th to the 3 rd centuries B.C. Berber groups ranged the Sahara, hunting and raiding, trading with, and settling among groups dwelling along the shrinking lakes and marshlands. ${ }^{7}$ Trans-Saharan links facilitated the spread of expertise in iron-working across the Sahara, probably by itinerant smiths who founded the endogamous blacksmith groups widely dispersed in western Africa. 8 It is noteworthy that from earliest times in western Africa smiths and their potter-wives have been associated with speakers of Mande languages. Almost certainly smiths served as the prototype for nyamakalaw(smiths, leatherworkers, and bards), occupational specialists set apart from the rest of society by their craft skills, knowledge of occult powers, and endogamous marriage patterns. Endogamy has the clear advantage of protecting professional secrets by imparting skills only to family members and selected apprentices, but the awesome powers attributed to members of nyamakalaw groups serves no less to set

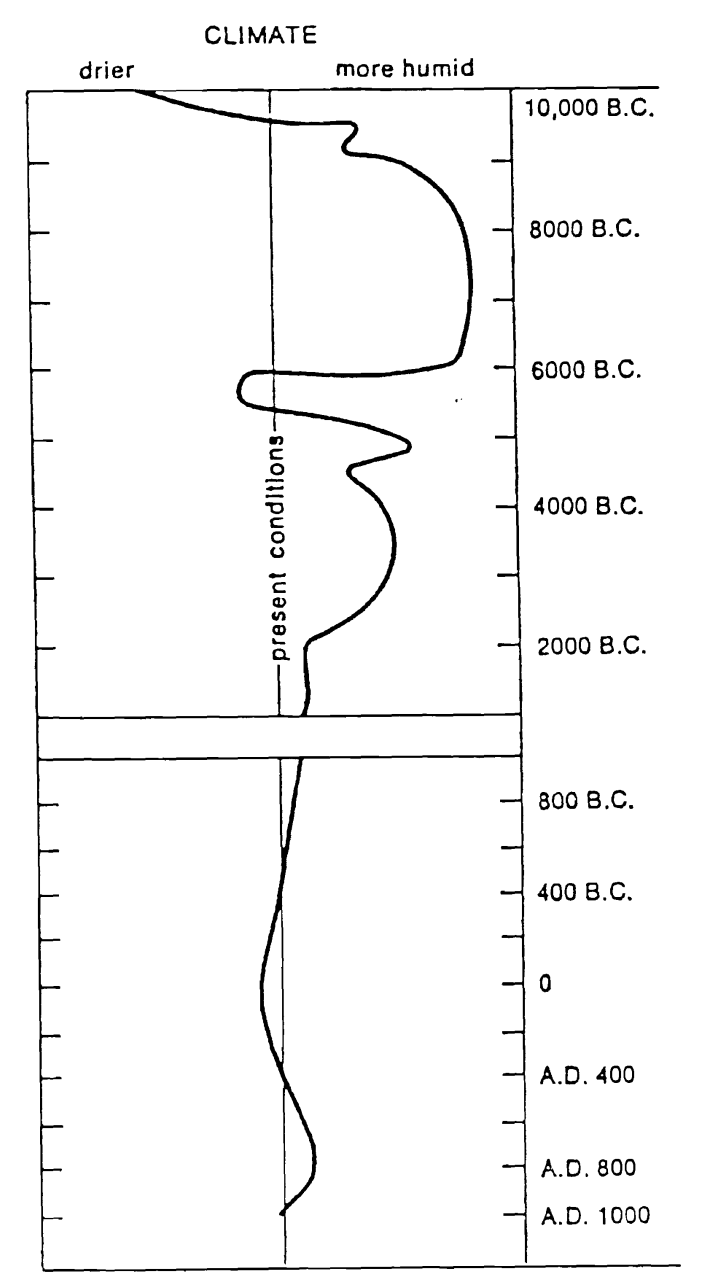

Figure 1

Prehistoric Climate Fluctuations in West Africa (McIntosh/McIntosh, "West African Prehistory," 604.) 
their members apart from other social elements. ${ }^{9}$ Likely the appearance of leatherworkers and bards dates to a considerably later period than smiths, as discussed following.

Occupying some of the most desirable territories of west Africa, possessing cattle, sheep, and goats, cultivating three staple grains, with skilled smiths to manufacture iron-tipped implements to till the land and iron weapons to defend it, Mande-speaking groups were well-prepared to take advantage of a favorable change in rainfall patterns.

(3) ca. 300 B.C.-ca. 300 A.D.; (4) ca. 300-ca. 700; and (5) ca. 700-ca. 1100

Rainfall in west Africa began to increase from approximately the beginning of the Christian era. For the purposes of discussion, it is convenient to treat as a continuum the ca. 300 B.C.-ca. 300 A.D. transition period, the ca. 300-ca. 700 period of moderate rainfall, and the ca. 700-ca. 1100 A.D. wet period.

Increasing rainfall from approximately B.C./A.D. onwards promoted the northward movement of herders exploiting pasturelands in the sahel zone and southern fringes of the Sahara, while cultivators growing millet, sorghum, and upland rice benefited from more reliable precipitation and were able to stay where they were. However, groups remaining in the more southerly areas during the increasingly humid climate which culminated in the ca. 700-1100 wet period would have been forced to make significant adaptations to changing environmental conditions.

It is likely that during the period of increasing rainfall from ca. B.C./A.D. onwards, and especially during the ca. 700-ca. 1100 wet phase, cultivatorsMande speakers and others-pioneered the development of new varieties of sorghum, millet, and upland rice suitable for the more humid climate conditions, as well as cultivating other foods and tending oil palms and karité/shea butter trees. ${ }^{10}$ Likewise, their ndama cattle, goats, and sheep would of necessity become acclimatized, the first two (but not sheep) acquiring immunities to tsetse-borne trypanosomes; note on Map 1 how far north the "tsetse fly line" $(1,000 \mathrm{~mm}$ isohyet) may have extended. Mande speakers and other groups associated with such adaptations would have been able to move south to new locations during the ca. 1100-ca. 1500 dry period. The differentiation of protoMande speakers into the Northern, Southwestern, and Southeastern sub-groups perhaps began earlier, but the separation of the three language sub-groups surely occurred during the time of wide geographical dispersion of Mande-speaking groups, from Saharan oases to the fertile plains of the inner Niger delta, and west to east over a vast territory. To the ecological adaptations of protoMande speaking groups may be added the social, cultural, and linguistic consequences of spatial separation over centuries. By the end of the ca. 700-ca. 1100 wet period, the northernmost and southernmost groups, separated by hundreds of kilometers, would have evolved significantly different lifestyles. The northern groups had acquired horses and zebu cattle from Berber nomads, and possibly camels, while the southern groups overtaken by the northward- moving savanna-woodland zone possessed ndama cattle, goats, and other domestic animals resistant to trypanosomes, and cultivated varieties of sorghum, millet, and upland rice adapted to the prevailing humid climate. Concomitantly, one may also assume increasing linguistic differentiation, which would have promoted the development of the three Mande sub-groups: Northern, associated with people living in the Sahara and sahel; and Southeastern and Southwestern, associated with groups living in the savanna and savannawoodland ecological zones.

Southeastern Mande groups seem likely to have developed commercial links with Kwa-speaking groups in present-day Ivory Coast during the ca. 700ca. 1100 wet period. Map 1 shows that the forest zone extended along the coast east of Cape Palmas, providing an environment suitable for malaguetta bushes, while the savanna-woodland zone reached far to the south. The location on Map 2 of remnant groups of Southeastern Mande speakers at the head of navigation of the Bandama and Sassandra rivers suggests trade links with Kwaspeaking mariners conveying pepper, salt, dried or smoked fish, and other commodities. Northern Mande-speaking groups were strategically located to participate advantageously in far-reaching economic, social, and cultural changes which became increasingly significant during the early centuries of the Christian era. Increasing rainfall promoted the use of camels in intra- and transSaharan commerce, stimulating the expansion of commercial networks linking peoples living in the desert, sahel, and savanna zones. Jenne-jeno and other riverine trading communities along the Bani and Niger rivers became inhabited by erine trading communities along the Bani and Niger rivers became inhabited growing numbers of fisherfolk, traders, smiths, potters, and other artisans. the origins of caravan and riverine routes transporting goods over long distances across ecological zones appears to date to the ca. 300 B.C.-ca. 300 A.D. arid period. Probably one of the first long distance routes supplanting relay commerce traversed the territories of Northern Mande-speaking groups dwelling between the eastern tributaries of the Senegal River and the western tributaries of the Niger River, the principal items of commerce being iron and iron manufactures, gold from Bambuk, and solar-evaporated salt from the Atlantic coast. The development of trans-Saharan routes during the $3 \mathrm{rd}($ ?) century A.D. provided an unprecedented stimulus to commerce and state-building in west Africa. ${ }^{12}$

Speakers of the Soninke dialect of the Northern Mande sub-group played a prominent role in these economic developments. Soninke elites were associated with rulership of Ghana, which state dated from the 6th century or earlier, likewise other states founded between the bends of the Niger and Senegal rivers in approximately the same period. ${ }^{13}$ The territory between the Niger and Senegal rivers was also the area where Mandekan dialects developed (see below). Responding to opportunities afforded by the expanding market economy, Mande-speaking smith-miners prospected farther and farther west and south in search of gold deposits and to profit from the sale of iron and iron products. Wherever they traveled, smiths practiced endogamy. Pioneer smiths speaking Northern Mande dialects who settled among West Atlantic speakers, 
Gur speakers, and other language groups adopted the dialects of their hosts and neighbors. The same was probably the case among many Southwestern and Southeastern Mande groups.

Circumstances were evidently different for smiths and traders who moved southwards along the upper tributaries of the Senegal and Niger rivers, for they continued to speak Northern Mande dialects. Northern Mande speakers living along the tributaries of the Senegal and Niger rivers were associated with different dialects and with different power associations--Susu/Jallonke/ Yalunka with Simo, and Vai/Kono with Poro. The west-east bifurcation of Susu/Jallonke/Yalunka vis-a-vis Vai/Kono correlates with the ongoing development of commercial networks along the Falémé and Bafing tributaries of the upper Senegal River and along the Milo, Dyon, and other tributaries of the upper Niger River. The separation of these Northern Mande dialects was subsequently compounded by movements farther south during the ca. 1100-ca. 1500 dry period when Susu/Jallonke/Yalunka speakers settled in Futa Jallon and Vai/Kono speakers settled in Sierra Leone and Liberia. The west- east differentiation of Susu/Jallonke/Yalunka and Vai/Kono dialects is paralleled by that of Simo and Poro power associations. One may speculate that Simo and Poro likewise derive from a common source, most probably Komo (or its progenitor), which survives today among Mandekan- (Maninka and Bamana) speaking groups in southern Mali along the headwaters of the Senegal and Niger river systems. ${ }^{14}$

The area separating the watersheds of the upper Senegal and upper Niger rivers was the core area for the gestation of Mandekan, the fourth branch of the Northern sub-group of Mande languages. Based on analyses of linguistic data, Charles S. Bird hypothesizes that perhaps a thousand years ago protoMandekan speakers occupied a triangular-shaped region "stretching perhaps from Segou in the north down to the headwaters of the Niger in the south and across to the Faleme in the west." 15 This "core area," as Map 1 shows, encompasses the Bambuk and Bouré gold fields, the most productive in western Africa, and the networks of west-east and north-south trade routes linking the Senegal and Niger rivers, Saharan entrepôts, and markets in the savannawoodland and forest zones supplying kola, malaguetta pepper, and other commodities.

Mandekan dialects are differentiated by five- and seven- vowel systems: Mandinka dialects to the west of the "core area" have five-vowel systems; Maninka dialects to the east of the "core area" have seven-vowel systems. The zone of demarcation runs north-south, passing through the Kita region and skirting the eastern borders of the Futa Jallon massif. The southwestward and southeastward extensions of Mandinka and Maninka speakers thus form two arcs encircling Futa Jallon, where few Mandekan-speaking horse warriors ventured (see following). The third major Mandekan dialect, Bamana, shares many of the attributes of Maninka and reflects the extensive southeasterly migrations of Mande traders and smiths, which increased significantly during the ca. $1630-$ ca. 1860 dry period and continue to the present-day. ${ }^{16}$
The Mandinka-Maninka linguistic separation also marks a socio-economic division: Mandinka speakers are oriented westwards by longstanding trade links reinforced during the 19 th and 20 th centuries by labor migration to Senegambia and the Guinea-Bissau region, while Maninka speakers are oriented eastwards towards the commercial centers of the savanna zone and southwards to the forest regions of Sierra Leone and Liberia.

Notwithstanding that the Mandinka/Maninka west-east dichotomy has important ramifications for linguistic and historical analyses, of greater significance, and one of the most striking features of Mandekan dialects, is the similarity of linguistic norms among dialects dispersed over vast areas of west Africa, most notably their high degree of syntactic regularity and simplicity. A multiplicity of economic, social, and cultural factors have combined to promote congruent developments in Mandekan dialects.

Bird delineates the interrelating factors that contributed to such similar linguistic developments in Mandekan dialects. He speculates that "a form of Pre-Mandekan came into being as a trade language and that, in a shift of cultural focus, the simplified rules of the trade language became the norms for the entire society." ${ }^{17}$ The development of syntactic regularity and simplicity would both have been fostered by, and have resulted from, the need for Mandekan speakers to communicate with peoples speaking other Mande dialects and belonging to other language groups encountered in markets and along trade routes of their commercial diaspora.

Peoples speaking other Mande dialects and other languages were constrained by circumstances to learn Mandekan dialects. These included individuals of all social groups among conquered societies ruled by the Mali empire (13th-15th centuries), but particularly the large numbers of captives taken in war or purchased by Mandekan speakers. A captive would have been strongly motivated to learn an owner's language, for this was a crucial step in assimilating to new social circumstances and changing from a non-person into one attached to a kin group and protectors. Slaves were extensively used as caravan porters and as soldiers, and contributed significantly to the spread of standardized and simplified Mandekan dialects. Together with traders, caravan porters were probably the principal diffusers of Mandekan dialects outside the Mandekan heartland. ${ }^{18}$

Improving climate conditions during the ca. 700 -ca. 1100 wet period facilitated trans-Saharan commerce, and horses were brought across the Sahara by Berbers following the Arab conquest of north Africa during the second half of the 7 th century. Soninke-speaking herders acquired a near-monopoly of horse breeding in sahelian pastures between the bends of the Senegal and Niger rivers, which control over the principal engine of war enabled Soninke horse warriors to dominate the grasslands. Conquests and state-building fostered the development of elite families associated with a warrior ethos and special claims to rulership. 
(6) ca. 1100-ca. 1500

The economic, social, and cultural developments previously discussed were accelerated and reinforced as a consequence of changes that occurred during the four-centuries-long dry period that began ca. 1100 A.D. Diminished rainfall caused ecological zones to move southwards, perhaps by several hundred kilometers over four centuries (Map 1), and historical accounts record droughts, desiccation, and far-ranging population movements. Mande-speaking traders, smiths, and warrior groups accommodated to the changing circumstances by moving south in what for purposes of analysis may be described as two stages: (a) traders and smiths, who were followed, as conditions allowed, by (b) horse warriors.

* As a consequence of desiccating conditions, Mande-speaking traders extended their commercial networks linking the Niger and Senegal rivers farther and farther south in order to expedite exchanges between ecological zones, some settling along the upper reaches of rivers navigated by West Atlantic and Kwa speaking maritime groups. The locations of surviving Southeastern Mandespeaking groups on Map 2 indicate that members of these groups were involved in trade in malaguetta pepper, kola, and other sylvan commodities. Mano, Dan/Gio, Kwene/Guro, and Mwa and Nwa remnant groups sited along the upper reaches and tributaries of the St. Paul, Cavalla, Sassandra, and Bandama rivers were conveniently located to expedite commerce with Kwa-speaking groups using these waterways to transport pepper, kola, and salt. Iron and iron manufactures, gold, and cotton cloth were probably the principal commodities bartered in exchange.

Mande smiths accompanied, or preceded, Mande traders, moving progressively farther south to exploit woodlands for charcoal-making in order to smelt and work iron and to open new markets for their manufactures. The areas they migrated from-- Senegambia and the lands along the northern borders of Futa Jallon--became increasingly more desiccated. The environment changed from savanna-woodland to savanna, and became suitable for the growth of cotton and the production of cotton textiles, large quantities of which were carried south by Mande traders to barter for kola, malaguetta pepper, other commodities available in the savanna-woodland and forest zones, and salt from coastal suppliers.

Mande-speaking traders and smiths contributed to the development of a number of commercial centers in the savanna-woodland zone which served local markets and became entrepots for trade with groups living in the forest zone and along the Atlantic coast. North to south in the savanna-woodland zone these included Kadé, Labé, Timbo, Falaba, Kissidougou, and, probably late in the ca. 1100-1500 dry period, Musadougou and Sondougou. Map 1 shows that all were located near the head of navigation of rivers linked to the Senegal River and Niger River commercial networks, and all are between 200 and 300 kilometers from the Atlantic Ocean, thereby well-situated to tap valuable resources of kola, malaguetta pepper, salt, and other savanna-woodland, forest, and coast- al-riverine products.

West Atlantic-, Gur-, and Kwa-speaking middlemen for their part protected longstanding commercial interests, denying Mande traders direct access to the coast and to important areas of production of kola, malaguetta pepper, and salt. The major exception was that of the Vai, who reached the coast in the Cape Mount area at the juncture of West Atlantic and Kruan language groups; seemingly this was the only approach to the coast accessible to Mande trading groups for hundreds of kilometers in either direction. ${ }^{19}$ Wherever Mande smiths and traders settled, they founded chapters of power associations which controlled and expedited commerce and served to educate and socialize their children and those of host societies. Viewed in the most basic terms, the spread of Komo, Simo, and Poro (and affiliated women's associations such as Bundu/Sande) demonstrated the concerns of smiths, traders, and other Mande migrants that their children be enculturated in Mande ways and that their communities receive leadership and spiritual protections. Smiths founded power association lodges wherever they settled, as Muslims built mosques in a later era. Leaders of Komo, Simo, and Poro were involved in all activities of the expatriate Mande community, and sought to exercise influence with host societies on its behalf, which they achieved to a progressively greater extent with time.

The means by which Komo, Simo, and Poro were successful in acquiring influence in host societies are manifest. Smiths possessed awesome attributes, including the ability to make powerful amulets and effect a variety of cures, in which latter they were seconded by Mande traders whose far-ranging commerce enabled them to acquire valuable information on medical treatments, including those introduced from north Africa by Muslim agency. Most important, and seemingly without exception, host societies entrusted their children to Komo, Simo, and Poro lodges and parallel female associations for instruction and induction into membership. In this way, Mande-controlled power associations increasingly came to influence and exercise control over local groups.

The ca. 1100-ca. 1500 dry period marked the apogee of horse warriors, who skillfully exploited the potential of cavalry to conquer vast territories across the sahel and savanna zones of west Africa. Bards chronicling this era explicitly recognized the significance of ecological factors, recording that Sundiata halted his campaigns at the limits of the land where karite/shea butter trees grew-the "bright country" extolled by bards. ${ }^{20}$ The era of the Mali empire (13th-15th centuries) saw a consolidation and elaboration of ongoing political and social developments among Northern Mande groups and their subjugated populations. Horse warrior state-builders imposed a stratified tripartite social structure: (a) elites and free persons; (b) nyamakalaw/endogamous occupational groups, comprising smiths, leatherworkers, and bards; and (c) large numbers of slaves, either captured during conquests or obtained through commerce. Traditions assert that this hierarchical social order was incorporated in the "constitution" promulgated by Sundiata's bard-spokesman, Balla Fasséké, following the defeat of Sumanguru, the Soso smith-sorcerer-warrior and 
leader of Komo. ${ }^{21}$

Nyamakalaw groups were subordinated to the interests of horse warrior elites. Smiths and leatherworkers manufactured the weapons and horse tack required by Mandekalu warriors, while bards helped to create and articulate a Mandekalu "heroic age" with the praise poetry and music they composed to celebrate the deeds of warriors and to describe and justify the social and cultural patterns they imposed on subjugated peoples. Bards were, and are, far more than passive reciters of others' deeds; they exercise an active, if indirect, role in public affairs by challenging their auditors to match or surpass the exploits of their predecessors. As validators of status and inciters to action, bards consciously manipulate, and endanger, the fundament of Mande society by exploiting the dialectical tension between the individual and the group. As Bird and Kendall explicate, heroes are "agents of social disequilibrium" whose acts threaten the fabric of society even as their achievements may further the common good, perhaps even be requisite to the group's survival. ${ }^{22}$

Bird emphasizes the unsurpassed role of bards in creating and reinforcing a strong sense of identity and pride among all Mandekan speakers. The extensive oral literature in Mandekan dialects is of particular importance, contributing to and exemplifying the Mandekalu identity, as well as reinforcing Mandekan linguistic norms. Bird suggests that the far-ranging bards "have functioned as an informal 'Academy,' exerting a normalizing force on the society's linguistic behavior." 23 Thus bards exercised a dual role-as rationalizing and defending Mandekalu political authority founded on tripartite social stratification, and as disseminators and role models regarding Mandekan dialects. Mandekalu conquests, Mandekan languages, and Mande cultural imperialism were mutually sustaining.

The latter part of the ca. 1100-ca. 1500 dry period marked the second phase of Mande expansion, as Mandekan-speaking horse warriors raided along the southerly-moving fringes of the savanna-woodland zone. Horse warriors and their retinues followed the caravan routes pioneered by Mande-speaking traders and smiths to pillage and to found conquest states acknowledging (nominal) tributary status to the Mali empire. Mandinka-speaking horsemen raided westwards into Senegambia and the Guinea-Bissau region, while Maninka speaking horsemen raided east and south around the outliers of Futa Jallon and along the tributaries of the upper Niger. Mande bulking and artisanal centers among West Atlantic and Gur host communities were especially attractive prizes for horse warriors, who used them as administrative headquarters to rule conquered territories and levy taxes on trading communities.

Mandekalu state-builders imposed linguistic, social, and cultural changes among conquered Mande-, West Atlantic-, and Gur-speaking groups. Likely many of these latter groups soon learned Mandekan languages, as did speakers of Southwestern and Southeastern Mande dialects who derived advantages from marriage alliances and commercial relationships with Mandekalu conquerors and their entourages. Comparing the extent of ecological zones during the ca. 1100- ca. 1500 and ca. 1630-1860 dry periods depicted on Map 1 with the sites of scattered populations of Southeastern and Southeastern Mandespeaking groups on Map 2 suggests that the survival of these groups owes much to their location south of the "tsetse fly line," where Mandekalu horse warriors were unable to conquer. The same would seem to be the case for the two southernmost Northern Mande-speaking groups, Susu/Jallonke/Yalonke and Vai/ Kono, likewise sufficiently far south to be protected from Mandekan-speaking horse warriors.

\section{(7) ca. 1500-ca. 1630}

Beginning ca. 1500 there was significantly greater rainfall for approximately a century-and-a-third, which in ecological terms is a relatively brief time span. Increased rainfall during the ca. 1500 -ca. 1630 wet period promoted the northward advance of the "tsetse fly line," perhaps by 200 kilometers or more (Map 1). The most rapid ecological changes may be presumed to have occurred in the north, where several years of increased precipitation would have significantly improved grazing areas in the Sahara, sahel, and northern savanna zones and enabled them to support larger numbers of pastoralists and their herds. The consequences of increased rainfall were likely less significant for cultivators in the savanna-woodland zone, and probably inconsequential for the inhabitants of the forest zone. Ecological changes during the ca. 1500-ca. 1630 wet period contributed to the defeat and disintegration of the Mali empire and subsequently that of its successor, the Songhai empire. The northward advance of the "tsetse fly line" forced the withdrawal of Mandekalu horse warriors from some of the areas they had conquered.

One of the consequences of the disintegration of the Mali empire was the dispersion of marauding Mandekalu horse warriors southwards into the Konyan highlands of Guinea-Conakry. Their marauding and the decline of the formerly prosperous commerce between Konyan and the Malaguetta coast caused smiths and traders living in the area to migrate with their families and dependents southwards and southwestwards through Liberia and Sierra Leone. These 'Mani' migrations spread Southwestern Mande dialects, including Mendi and Loko, and Mande social and cultural attributes, most notably the Poro power association. Poro spread even where the Mani invaders were too few to impose Mande languages over conquered West Atlantic speaking Bullom and Temni groups. 24

\section{(8) ca. 1630 -ca. 1860}

The brief ca. 1500-ca. 1630 wet period was succeeded by a long dry period lasting until ca. 1860 during which ecological zones moved southwards hundreds of kilometers in some areas. Mandekalu horse warriors opportunistically renewed their raids southwards along the receding borderlands of the savannawoodland zone, selling captives into the rapidly-growing Atlantic slave trade during the 17 th and 18 th centuries. This was the era of the Mandinka-ruled 
Kaabu empire, whose elites and their retinues ravaged West Atlanticspeaking groups living between the Gambia River and the foothills of Futa Jallon.

Expanding Mandinka hegemony in western Africa was arrested and eventually destroyed by the potent combination of two elements: the augmentation of Fula military capabilities in cavalry warfare against Mandinka elites; and the dynamic leadership provided by militant Torodbe clerisy in uniting dispersed Fula groups. During the 1720 s a Torodbe-led jihad gained control over the Futa Jallon highlands surrounding Labe and Timbo, and during the next 150 years the armies of the Fula almamate annexed the entire massif and expanded Fula suzerainty over neighboring areas. Many Susu speakers fled south to the coastal region of Guinea-Conakry (where they are called "Susu"), while others (the "Jallonke" or "Yalunka") settled in the eastern ranges of the massif along the borderlands of Guinea-Conakry and Sierra Leone. Kaabu was destroyed in the mid-19th century by the combined forces of local Fula and Fula armies dispatched from Futa Jallon, and its territories were incorporated into the Fularuled state of Fuladu. Concomitantly, in 1852 the Torodo leader Al Hadj Umar launched a jihad northwards from Futa Jallon directed mainly against Bamana and other Mande-speaking groups. By the time of his death in 1864, Al Hadj Umar's forces had conquered a vast area between the upper Senegal and upper Niger river valleys, the ancient homeland of the Northern Mande sub-group.

Had France and Britain not conquered western Africa at the close of the 19th century, Fula hegemony and Fula cultural and linguistic imperialism might have supplanted those of Mande-speaking groups. Given a respite, Mande languages, institutions, and cultural patterns survived and continued to expand in west Africa: the overwhelming majority of people in western Africa speak a Mande dialect as a first or second language and have adopted many social and cultural attributes of Mande-speaking peoples.

\section{III}

As the foregoing discussion emphasizes, many factors influenced the diffusion of Mande-speaking groups in west Africa and their success in imposing and persuading other groups to adopt their languages, institutions, and cultural patterns. Indubitably foremost among these were climate and ecological factors that determined where Mande-speaking groups might travel, and for what purposes.

\section{NOTES}

* An earlier version of this paper was presented at the African Studies Association meeting convened in Denver, 20-22 November 1987. I am indebted to C. S. Bird, M. G. Kendall, and P. R. McNaughton for many informative discussions over the years. E. C. Rivron contributed to numerous improvements in analysis and presentation.

1. Sharon E. Nicholson, "The Methodology of Historical Climate Reconstruction and its Application to Africa," JAH, 20, 1 (1979), 31-49; Susan Keech McIntosh and Roderick J. McIntosh, "West African Prehistory," American Scientist, 69, (1981), 602-13; George E. Brooks, Western Africa to ca. 1860 A.D.: A Provisional Historical Schema Based on Climate Periods (Bloomington, 1985); idem., "A Provisional Historical Schema for Western Africa Based on Seven Climate Periods (ca. 9000 B.C. to the 19th Century)," Cahiers d'Etudes Africaines, 101-02 (1986), 43-62.

2. Joseph C. Greenberg, The Languages of Africa (Bloomington, 1963); Charles S. Bird, "The Development of Mandekan (Manding); A Study of the Role of ExtraLinguistic Factors in Linguistic Change" in David Dalby, ed., Language and History in Africa (New York, 1970), 146-59; idem., The Dialects of Mandekan (Bloomington, 1982).

3. McIntosh/McIntosh, "West African Prehistory," 604

4. J. E. G. Sutton, "The Aquatic Civilization of Middle Africa," JAH, 15 (1974), 527-46; Henri Lhote, A la découverte des fresques du Tassili (Grenoble 1958).

5. Thurstan Shaw, "The Late Stone Age in West Africa" in J.A. Allan, ed., The Sahara: Economic Change and Early Economic History (Outwell, 1981), 102-05 and figure 10; S.K. McIntosh and R.J. McIntosh, "Current Directions in West African Prehistory," Annual Review of Anthropology, 12 (1983), 238-39; Patrick J. Munson, "Archaeology and the Prehistoric Origins of the Ghana Empire," JAH, 21 (1980), 462-63.

6. McIntosh/McIntosh, "Current Directions," 238.

7. Henri Lhote, Les chars rupestres sahariens: des Syrtes au Niger, par les 'pays des Garamantes et des Atlantes' (Toulouse, 1982); Munson, "Ghana Empire," 462-65.

8. McIntosh/McIntosh, "West African Prehistory," 610.

9. Brooks, Western Africa, 128-29; Patrick R. McNaughton, "Nyamakalaw: the Mande Bards and Blacksmiths" (unpublished paper, 1982); idem., "Daliluw: a Mande Application of Science and Sorcery" (unpublished paper, 1982); idem., The Mande Blacksmiths; Knowledge, Power, and Art in West Africa (Bloomington, 1988), chapter 1.

10. George Murdock, Africa; Its Peoples and their Culture History (New York, 1959), $64-71$.

11. McIntosh/McIntosh, "The Inland Niger Delta Before the Empire of Mali: Evidence from Jenne-Jeno," JAH, 22 (1981), 10-21.

12. Brooks, Western Africa, 30-31.

13. Susan Keech McIntosh, "A Reconsideration of Wangara/Palolus, Island of Gold," JAH, 22 (1981), 154-57; Munson, " Ghana Empire," 462-63; B. Marie Perinbam, "Notes on Dyula Origins and Nomenclature," BIFAN, 26 (1974), 679-80.

14. Brooks, Western Africa, 133-36; G. Diertelen and Y. Cissé, Les Fondaments de la société d'initiation du komo (Paris, 1972), 9-10, 15- 20; Patrick R. McNaughton, Secret Sculptures of Komo; Art and Power in Bamana (Bambara) Initiation Associations (Philadelphia, 1979), 8.

15. Bird, "Development of Mandekan," 149

16. Bird, Dialects of Mandekan, 1-5, 352.

17. Bird, "Development of Mandekan," 154.

18. Ibid., 154-55.

19. Brooks, Western Africa, 101-07.

20.Djibril Tamsir Niane, "Recherches sur l'empire du Mali au moyen âge; le problème de Soundjata," Recherches Africaines/Etudes Guinéenes, 1 (1960), 20-21; idem., Sundiata: an Epic of Old Mali (London, 1965), 2.

21. Niane, Sundiata, 73-78.

22. Charles S. Bird and Martha B. Kendall, "The Mande Hero" in Ivan Karp and Charles S. Bird, eds., Explorations in African Systems of Thought (Bloomington, 1980), 13-16. 
23. Bird, "Development of Mandekan," 156.

24. Walter Rodney, "A Reconstruction of the Mane Invasions of Sierra Leone," JAH, 8, 2 (1967), 219-46; idem., A History of the Upper Guinea Coast (Oxford, 1970), 39-70; Yves Person, "Ethnic Movements and Acculturation in Upper Guinea since the Fifteenth Century," IJAHS, 4 (1971), 669-89; Brooks, Western Africa, 161-64, 168-77.

\section{"BILALI OF FARANSEKILA": A WEST AFRICAN HUNTER AND WORLD WAR I HERO ACCORDING TO A WORLD WAR II VETERAN AND HUNTERS' SINGER OF MALI}

\author{
David C. Conrad \\ SUNY-Oswego
}

"An only son must never die in war until the end of the world."

(Seydou Camara, "Bilali of Faransekila," 1:396)

Discussing the significance of Kande Kamara's oral history of West African experiences in the First World War, Joe Harris Lunn observes that, although historians have begun to examine the effects of that war on west Africa, their studies are mostly based on written sources, "and therefore shed little light on the lived reality of the war for the African masses whose perceptions of their experiences were never recorded." Of particular value then, is the oral history provided by the Guinean veteran Kande Kamara, offering as it does an opportunity for assessing the European war's impact on west Africans. Lunn finds, however, that west African soldiers who served in France during the First World War have left very few records of either their wartime experiences or its effects on their later lives. ${ }^{1}$ The text by the late Malian hunters' singer Seydou Camara that is presented here helps to redress this lamentable deficiency because, although it is a step or two removed from the sort of firsthand eyewitness account offered by Kande Kamara, it provides valuable support for and confirmation of certain elements of Kande Kamara's testimony. Composed and sung by Seydou Camara, "Bilali of Faransekila". provides us with an oral traditional counterpart to Kande Kamara's firsthand account. $^{2}$

According to Vansina's taxonomy among the different types of non-written sources that provide useful historical information, oral history like the document by Kande Kamara, is the most reliable because it consists, among other things, of eyewitness accounts of events that occurred during the lifetime of the informants. A distinct advantage for historians working with oral histories is 